\title{
Soy Saponins Meditate the Progression of Colon Cancer in Rats by Inhibiting the Activity of $\beta$-Glucuronidase and the Number of Aberrant Crypt Foci but Not Cyclooxygenase-2 Activity
}

\author{
Yu-Wei Guo, Yue-Hwa Chen, Wan-Chun Chiu, Hsiang Liao, and Shyh-Hsiang Lin \\ School of Nutrition and Health Sciences, Taipei Medical University, $250 \mathrm{Wu}$-Hsing Street, Taipei 110, Taiwan \\ Correspondence should be addressed to Shyh-Hsiang Lin; lin5611@tmu.edu.tw
}

Received 30 May 2013; Accepted 28 July 2013

Academic Editors: Z. S. Guo, S. Honoré, N. Sharma-Walia, and Y. Yu

Copyright @ $2013 \mathrm{Yu}-$ Wei Guo et al. This is an open access article distributed under the Creative Commons Attribution License, which permits unrestricted use, distribution, and reproduction in any medium, provided the original work is properly cited.

\begin{abstract}
Objective. The effect of extracted crude soybean saponins on preneoplastic lesions, aberrant crypt foci (ACF), and the related mechanism were investigated. Research Methods and Procedures. Rats were assigned into five groups according to different doses of extracted crude soybean saponins and received 1,2-dimethylhydrazine (DMH) injection in week 5. In week 15, all rats were sacrificed. The number of ACFs, the cyclooxygenase-2 (COX-2) protein expression, the level of prostaglandins E2 (PGE2), and the activity of $\beta$-glucuronidase were examined. Results. Results revealed that the consumption of extracted crude soybean saponins decreased the number of ACFs and the activity of $\beta$-glucuronidase in rats, while the expression of COX- 2 protein and PGE2 level were not affected. Conclusions. Soybean saponins were effective in inhibiting colon cancer by downregulating the activity of $\beta$ glucuronidase in colonic mucosa but not the COX-2 protein expression and PGE2 level.
\end{abstract}

\section{Introduction}

Dietary habit is one of the major factors that cause colon cancer. It was reported that the colon cancer mortalities are higher in the countries where people consume more animal fat [1]. On the other hand, fiber-rich foods increase the volume of feces and promote the creeping motion of the large intestine, hence, reduce the contacting time of carcinogens in the body [2]. The development of tumor cells the early stage is closely related to inflammatory responses. Immune response factors such as cytokines, reactive oxygen species (ROS), proinflammatory enzyme cyclooxygenase- 2 (COX-2), and nitric oxide synthase (iNOS) may accelerate the development of cancer [3]. It has been indicated that colon cancer progression could be slowed down by reducing the expression of COX-2 protein or reducing inflammatory reaction $[4,5]$. At the location of inflammation, iNOS may cause the overproduction of nitric oxide, which results in damages on DNA repair and promotes the proliferation of cancer cells [6]. In the early stage of colon cancer in human, lowering the expression of iNOS could be used to reduce the formation of cancer cells [7]. In addition, carcinogens may increase the activities of COX-2 and iNOS on the mucosa of the colon, which also causes the promotion of cancer occurrence [7]. Both COX-2 and iNOS are upregulated by $\mathrm{NF}-\kappa \mathrm{B}$. It was indicated that by reducing NF- $\kappa \mathrm{B}$ expression, the occurrence of cancer can be reduced [8].

There are several enzymes other than immune response factors, such as nitroreductase, azoreductase, and $\beta$ glucuronidase produced by the bacteria in the intestine, that are closely related to cancer occurrence. Those enzymes may convert some procarcinogens to carcinogens [9]. Hence, by inhibiting the activities of those enzymes, the chance of cancer formation can also be reduced.

Soy saponins are amphiphilic compounds and can binnd to the phospholipids and cholesterol with the hydroxyl groups on the aglycone moiety of the compounds [10], hence, change the structure of the cell membrane. Soy saponins have been found to have inhibitory effects in vitro on cancer cells [11] by changing the cell morphology, cell proliferation enzymes, and cell growth. In this study, we investigated the effect and mechanism of soy saponins on preventing colon cancer in rats by observing the formation of aberrant crypt foci (ACF) as well as measuring the inflammatory factors, 
TABLE 1: Diet composition in each group.

\begin{tabular}{lccccc}
\hline (g/kg) & DS0 & DS0.5 & DS1 & PS0 & PS0.5 \\
\hline Corn starch & 529.5 & 529.5 & 529.5 & 529.5 & 529.5 \\
Casein & 200 & 200 & 200 & 200 & 200 \\
Sucrose & 100 & 95 & 90 & 100 & 95 \\
Cellulose & 50 & 50 & 50 & 50 & 50 \\
Soybean oil & 70 & 70 & 70 & 70 & 70 \\
Mineral mix ${ }^{1}$ & 35 & 35 & 35 & 35 & 35 \\
Vitamin mix ${ }^{1,2}$ & 10 & 10 & 10 & 10 & 10 \\
L-cystine & 3 & 3 & 3 & 3 & 3 \\
Choline & 2.5 & 2.5 & 2.5 & 2.5 & 2.5 \\
T-butylhydroquinine & 0.014 & 0.014 & 0.014 & 0.014 & 0.014 \\
Crude saponins & - & 5 & 10 & - & 5 \\
\hline Energy (kcal/kg) & 4147.94 & 4147.9 & 4147.94 & 4147.94 & 4147.94 \\
\hline
\end{tabular}

${ }^{1}$ The composition of AIN-93 vitamin mixture and AIN-93 mineral mixture. Mixtures are as described in the American Institute of Nutrition [42].

${ }^{2}$ Containing Vitamin A palmitate $1.6 \mathrm{~g} / \mathrm{kg}$.

$\mathrm{NF}-\kappa \mathrm{B}, \mathrm{COX}-2$, and iNOS, and enzyme activities in the large intestine of rats.

\section{Materials and Methods}

2.1. Animals and Sample Collection. Fifty male Fisher 344 rats, six weeks old, were housed in iron cages (2/cage) and kept under the 12/12 hours light-dark conditions of $50 \%$ humidity and a temperature of $23^{\circ} \mathrm{C}$. Food and water were available ad libitum. Animals were fasted overnight and weighed before sacrifice. Rats were assigned into five groups (Table 1). Modified AIN93G was used as the control (basal) diet. From week 0, rats in DS0, DS0.5, and DS1 consumed the diet containing $0 \%, 0.5 \%, 1 \%$ soy saponin, respectively, for four weeks before receiving dimethylhydrazine (DMH) injections (20 mg/kg-BW, 2 times/week) for the following 6 weeks. Rats in PS0 and PS0.5 groups consumed the basal diet plus $0 \%$ and $0.5 \%$ of soy saponins, respectively, before receiving saline injections $(2 \mathrm{~mL} / \mathrm{kg} \mathrm{BW}, 2$ times/week) for the following 6 weeks. The blood samples were collected in week 0 and week 15 . At the end of week 15 , all rats were sacrificed.

2.2. Preparation of Soy Saponin. Soy saponin were extracted by applying and modifying the method previously reported [12]. The purity of crude saponins extracted was examined by HPLC (TSP, Germany) with commercial soy saponins as the standards (Wako, Japan). The HPLC condition was as follows: C18 column (Vercopak, ODS-3, $4.6 \times 250 \mathrm{~mm}$ ); UV absorbance: $190-350 \mathrm{~nm}$; analyzing temperature: $30^{\circ} \mathrm{C}$; flow rate: $1 \mathrm{~mL} / \mathrm{min}$; gradient solvent system: solvent $\mathrm{A}, 0.05 \%$ trifluoroacetic acid in water and solvent $\mathrm{B}$, acetonitrile. The gradient program was set as $63 \% \mathrm{~A}$ to $52 \% \mathrm{~A}$ in $38 \mathrm{~min}$.

Blood samples were drown from the abdominal cavity vein and collected in tubes containing heparin at the end of the experiment. The liver was purged with phosphate buffer saline (PBS) and stored in formaldehyde, followed by an observation using $\mathrm{H} \& \mathrm{E}$ stain. The rectum and colon samples were collected and washed with PBS and then stored at $-80^{\circ} \mathrm{C}$. The average length of the rectum $(n=4)$ of each group was recorded. The colon was divided into 3 sections, near cecum section, middle section, and near anus section.

2.3. Isoflavones Quantification. Isoflavone standards were prepared using commercially available $25 \mathrm{ppm}$ Daidzin (30408, Fluka), Daidzein (Wako), Genistein (G6649, Sigma) and Genistin (G0897, Sigma). Samples, dissolved in $20 \mathrm{~mL}$ $80 \%$ methanol (MS1992, Tedia), were prepared from $0.5 \mathrm{~g}$ crude soy saponins extract. A high performance liquid chromatography (HPLC) method was used for analysis with C18 column (Inertsil 6, ODS-3, $4.6 \times 250 \mathrm{~mm}$, Vercopak). The injection volume was $20 \mu \mathrm{L}$. The column temperature was kept constant at $40^{\circ} \mathrm{C}$ (Super CO-150, Enshine) and the flow rate was $1 \mathrm{~mL} / \mathrm{min}$. The UV detection wavelength was set at $248 \mathrm{~nm}$. The binary gradient elution system consisted of two solvents: acetonitrile (A) and acetic acid ( $0.1 \%$ in water, B). Separation was achieved using the following gradient: solvent A, $1-4 \mathrm{~min}, 15 \% \rightarrow 35 \%$; 04-48 $\mathrm{min}, 35 \%$.

2.4. Plasma Isoflavones Level. The isoflavones in the plasma were extracted with tert-butyl methyl ester (TBME) and analyzed with HPLC with C18 column (Inertsil 6, ODS$3,4.6 \times 250 \mathrm{~mm}$, Vercopak) at $40^{\circ} \mathrm{C}$. The UV detection wavelength was set at $248 \mathrm{~nm}$ and the mobile phase was methanol : ammonium acetate $(0.1 \mathrm{M})(40: 60(\mathrm{pH} 4.7))$.

2.5. Plasma Lipid Analysis. The plasma lipid analysis was performed by using automatic biochemical analyzer (Dri-Chem 3500, Fuji) for total triglyceride (TG) and total cholesterol (TC) determination.

2.6. Aberrant Crypt Foci (ACF) Observation. A colon sample was fixed in $10 \%$ formalin for $24 \mathrm{hr}$ and flushed with saline on a filter, then dipped in $0.5 \%$ methylene blue for $1 \mathrm{~min}$, followed by being washed with distilled water briefly and placed on a microscope slide with the mucosal surface up. The ACFs were classified into: (A) normal crypt, (B) 1 aberrant crypt (AC)/ACF, (C) $2 \mathrm{AC} / \mathrm{ACF}$ and (D) $3 \mathrm{AC} / \mathrm{ACF}$. Then the ACFs containing 1-3 ACs were defined as small ACFs, and those containing more than $3 \mathrm{ACs}$ were large ACFs. The numbers of small, large, and total ACFs were determined.

\subsection{COX-2 Protein Expression in the Colon Mucosa}

2.7.1. Protein Determination. Cell protein was extracted and determined using the commercial protein assay kit (BCA1 and B9643, Sigma). Briefly, $200 \mu \mathrm{L}$ of BCA assay reagent (bicinchoninic acid solution: copper sulfate pentahydrate $4 \%$ solution $(50: 1))$ was completely mixed with a sample and incubated for $30 \mathrm{~min}$ at $37^{\circ} \mathrm{C}$. The O.D. was measured at $562 \mathrm{~nm}$.

The COX-2 $(\mathrm{MW}=70 \mathrm{kDa})$ and the iNOS $(\mathrm{MW}=$ $130 \mathrm{kDa}$ ) protein expressions were measured by using SDSPAGE with 10\% resolving gel and 7\% stacking gel followed by western blotting while $\beta$-actin $(42 \mathrm{kDa})$ was used as an 
internal control. The primary and secondary antibodies were as follows:

Primary Antibodies. $\beta$-actin (mouse anti- $\beta$-actin monoclonal antibody, A 5441, SIGMA); COX-2 (goat anti-COX monoclonal antibody, sc-19999, Santa Cruz); iNOS (rabbit antiNOS2 polyclonal antibody, sc-649, Santa Cruz) diluted in TBST $(1: 1000)$ which obtained $1 \%$ BSA.

Second Antibodies. $\beta$-actin (rabbit anti-mouse IgG, A9044, SIGMA); COX-2 (donkey anti-mouse IgG, sc-2020, Santa Cruz); iNOS (goat anti-rabbit IgG, sc-2004, Santa Cruz).

2.8. PGE2 Level in the Colon Mucosa. A colon mucosa sample was homogenized and adjusted to $\mathrm{pH} 7.2$ and then mixed with 2-4 times volume of acetone and incubated for $5 \mathrm{~min}$ in room temperature. The sample was centrifuged at $1500 \times \mathrm{g}$ for $10 \mathrm{~min}$. The acetone in the supernatant was removed and the PGE2 was determined with commercial kit (Prostaglandin $\mathrm{E}_{2}$ EIA Kit, Cayman). The homogenization buffer was prepared by dissolving $13.69 \mathrm{~g}$ phosphate in $\mathrm{dd}_{2} \mathrm{O}$ containing $357.8 \mathrm{mg}$ EDTA and $3.6 \mathrm{mg}$ indomethacin and adding $\mathrm{ddH}_{2} \mathrm{O}$ to $1000 \mathrm{~mL}$ (adjust $\mathrm{pH}$ to 7.4 ).

2.9. $\beta$-Glucuronidase Enzyme Activity. A sample of $20 \mu \mathrm{L}$ and $200 \mu \mathrm{L}$ GUS (31.5 mg pNPG, N-1627, Sigma, dissolved in $100 \mathrm{~mL} 50 \mathrm{mM} \mathrm{Na} \mathrm{PO}_{4}, \mathrm{pH} 7.0$ ) were mixed well, followed by performing an enzyme-linked immunosorbent assay (ELISA) at $415 \mathrm{~nm}$ every $10 \mathrm{~min}$ for an hour. The enzyme activity was acquired according to the Lowry method [13].

2.10. Liver Biopsy. Liver samples were stained with Hematoxylin and eosin ( $\mathrm{H} \& \mathrm{E}$ ) dye and subjected to pathological observation.

2.11. Statistical Analysis. Data were analyzed with one-way analysis of variance (ANOVA) followed by Fisher's least Significant Differences (LSD) and Dunnett post hoc analysis. All values were expressed as the mean value \pm SEM. All group comparisons were considered significant at $P<0.05$.

\section{Results}

3.1. Saponin and Isoflavone Content. One gram of the soy extract contains saponin $778.3 \pm 3.8 \mathrm{mg}$ and isoflavone $2.8 \pm$ $0.3 \mathrm{mg}$, including daidzin $1180 \pm 44 \mu \mathrm{g}$, genistin $923 \pm 11 \mu \mathrm{g}$, daidzein $173 \pm 58 \mu \mathrm{g}$, and genistein $474 \pm 197 \mu \mathrm{g}$.

3.2. Food Intake, Body Weight, and the Organ Weight of the Rats. The average body weight of rats in all groups increased as the experiment proceeded but was not significant between groups. The average change per day in body weight was $1.77 \pm$ $0.04 \mathrm{~g}$ in DS0, $1.68 \pm 0.06 \mathrm{~g}$ in DS0.5, $1.79 \pm 0.06 \mathrm{~g}$ in DS1, $1.86 \pm 0.06 \mathrm{~g}$ in PS0, and $1.85 \pm 0.08 \mathrm{~g}$ in PS0.5. Those receiving $\mathrm{DMH}$ injection tended to have a lower body weight increase compared to those receiving saline injection. The average daily food intake of rats was $16.44 \pm 0.26 \mathrm{~g}$ in DS0, $15.45 \pm$ $0.35 \mathrm{~g}$ in DS0.5, $15.95 \pm 0.33 \mathrm{~g}$ in DS1, $16.78 \pm 0.24 \mathrm{~g}$ in PS0, and $15.85 \pm 0.38 \mathrm{~g}$ in PS0.5. There was no significant difference

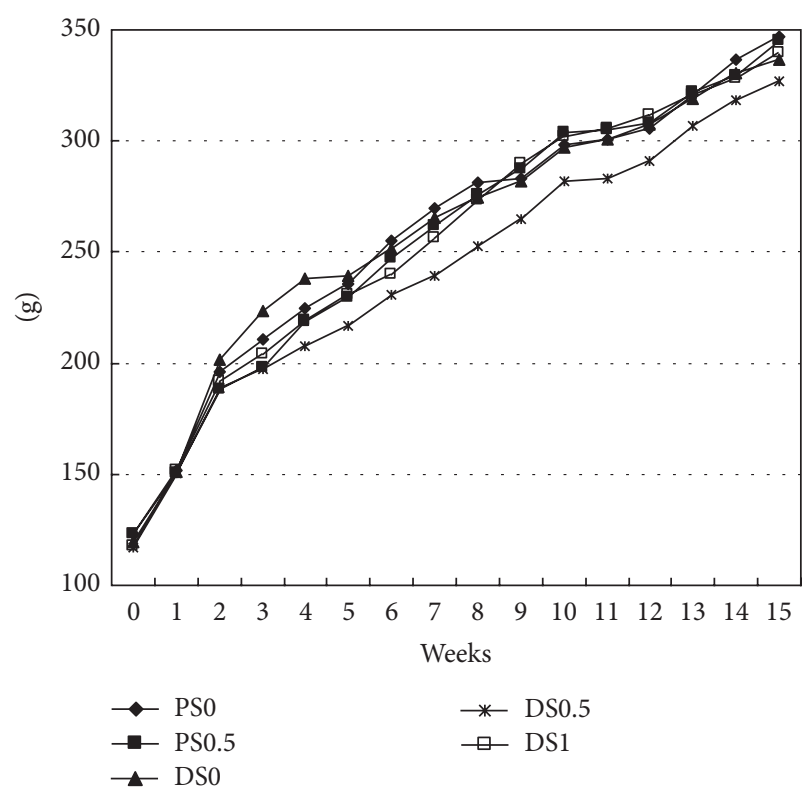

FIGURE 1: Body weights of rats in the experimental period ${ }^{1,2} \cdot{ }^{1} \mathrm{PS} 0$ : received saline and fed AIN93G diet; PS0.5: received saline and fed AIN93G diet containing $0.5 \%$ saponins; DSO: received 1,2dimethylhydrazine (DMH) and fed AIN93G diet; DS0.5: received DMH and fed AIN93G diet containing 0.5\% saponins; DS1: received $\mathrm{DMH}$ and fed AIN93G diet containing $1 \%$ saponins. ${ }^{2}$ There was no statistic difference between each other $(P>0.05)$.

in average daily food intake. The addition of soy extract and injection of DMH did not alter the food consumption (Figure 1). The percentage of the liver weight in body weight was $3.80 \pm 0.09 \%$ in DS0, $3.77 \pm 0.15 \%$ in DS0.5, $3.41 \pm 0.13 \%$ in DS1, $3.79 \pm 0.12 \%$ in PSO, and $3.58 \pm 0.19 \%$ in PS0.5, and no statistical difference was found. No significant difference in the length and weight of the colon was detected among groups either.

3.3. Aberrant Crypt Foci (ACF) and Cyclooxygenase-2. ACFs with 1-3 aberrant crypts (ACs) are classified as "small" ACFs, and those with more than $3 \mathrm{AC}$ are "large" ACFs [14]. Our results show that the numbers of small ACFs were negatively correlated to saponin dosages $(P<0.05$, Table 2$)$. Also, rats in DS1 group had a lower count of large ACFs ( $>3$ ACs) than those in DS0 group did $(P<0.05$, Table 3$)$. The results also show that there were aberrant crypt foci (ACFs) with 16 aberrant crypts (AC) in the DS0, DS0.5, and DS1 groups (Figure 2). No ACFs were found in the PS0 and PS0.5 groups.

On the other hand, the DS1 group had a lower number of total ACFs in the cecum region than the DS0 group did $(P<0.05)$. In the middle section of the colon, DS1 group had less ACFs than DS0 group and DS0.5 group $(P<0.05)$. At the anal end, the DS0.5 group and the DS1 group had lower total ACFs than the DS0 group $(P<0.05)$. In the whole colon section, the ACFs numbers were negatively correlated to the dose of saponin treated in the experiment $(P<0.05)$ (Table 4). 
TABLE 2: The counts of small ACFs in rats ${ }^{1,2}$.

\begin{tabular}{lccccc}
\hline & ${\text { The incidence of } \mathrm{ACFs}^{3}}^{3}$ & $1 \mathrm{AC}$ & $2 \mathrm{AC}$ & 3AC & Small \\
\hline PS0 & $0 / 4$ & $\mathrm{ND}^{5}$ & $\mathrm{ND}$ & $\mathrm{ND}$ & ND \\
PS0.5 & $0 / 4$ & $\mathrm{ND}$ & $\mathrm{ND}$ & $5.83 \pm 0.70$ & $25.00 \pm 1.89^{\mathrm{a}}$ \\
DS0 & $6 / 6$ & $10.16 \pm 1.22^{\mathrm{a}}$ & $9.00 \pm 1.46^{\mathrm{a}}$ & $3.83 \pm 0.41$ & $15.50 \pm 0.54^{\mathrm{b}}$ \\
DS0.5 & $6 / 6$ & $5.67 \pm 0.59^{\mathrm{ab}}$ & $6.00 \pm 0.75^{\mathrm{ab}}$ & $3.00 \pm 0.63$ & $7.67 \pm 1.32^{\mathrm{c}}$ \\
DS1 & $6 / 6$ & $2.83 \pm 0.39^{\mathrm{b}}$ & $1.83 \pm 0.50^{\mathrm{b}}$ & & \\
\hline
\end{tabular}

${ }^{1}$ Data are expressed as mean $\pm \operatorname{SEM}(n=6)$.

${ }^{2}$ PS0: received saline and fed AIN93G diet; PS0.5: received saline and fed AIN93G diet containing 0.5\% saponins; DS0: received 1,2-dimethylhydrazine (DMH) and fed AIN93G diet; DS0.5: received DMH and fed AIN93G diet containing 0.5\% saponins; DS1: received DMH and fed AIN93G diet containing 1\% saponins.

${ }^{3}$ The incidence of ACFs is the number of ACF rats/the number of total rats.

${ }^{4}$ Small ACFs: 1 3AC/ACF.

${ }^{5} \mathrm{ND}$ : No detection.

${ }^{\mathrm{abc}}$ Letters in each column sharing the different superscripts are significantly different $(P<0.05)$.

TABLE 3: The counts of large ACFs in rats ${ }^{1,2}$.

\begin{tabular}{lccccc}
\hline & The incidence of $\mathrm{ACFs}^{3}$ & $4 \mathrm{AC}$ & $5 \mathrm{AC}$ & 6AC & Narge \\
\hline PS0 & $0 / 4$ & $\mathrm{ND}^{5}$ & $\mathrm{ND}$ & ND & ND \\
PS0.5 & $0 / 4$ & $\mathrm{ND}$ & $\mathrm{ND}$ & $0.17 \pm 0.09$ & $2.00 \pm 0.20^{\mathrm{a}}$ \\
DS0 & $6 / 6$ & $1.67 \pm 0.27$ & $0.17 \pm 0.09$ & $\mathrm{ND}$ & $1.17 \pm 0.17^{\mathrm{ab}}$ \\
DS0.5 & $6 / 6$ & $1.17 \pm 0.17$ & $\mathrm{ND}$ & $\mathrm{ND}$ & $0.33 \pm 0.12^{\mathrm{b}}$ \\
DS1 & $6 / 6$ & $0.17 \pm 0.09$ & $0.17 \pm 0.09$ & &
\end{tabular}

${ }^{1}$ Data are expressed as mean $\pm \operatorname{SEM}(n=6)$.

${ }^{2}$ PS0: received saline and fed AIN93G diet; PS0.5: received saline and fed AIN93G diet containing 0.5\% saponins; DS0: received 1,2-dimethylhydrazine (DMH) and fed AIN93G diet; DS0.5: received DMH and fed AIN93G diet containing 0.5\% saponins; DS1: received DMH and fed AIN93G diet containing 1\% saponins.

${ }^{3}$ The incidence of ACFs is the number of ACF rats/the number of total rats.

${ }^{4}$ Large ACFs: $>3 \mathrm{AC} / \mathrm{ACF}$.

${ }^{5}$ ND: No detection.

${ }^{\mathrm{ab}}$ Letters in each column sharing the different superscripts are significantly different $(P<0.05)$.

After the injection of DMH, the expressions of COX-2 protein were more significant in the saponin-treated groups (DS0, DS0.5, and DS1) than the PS groups, however, not significant among the DS0, DS0.5, and DS1 groups, and there was no COX-2 expression in the PS groups. There was no significant difference in the colon section regarding the expression of COX-2, while no change in iNOS expression was detected in the experiment (Figures 3(b) and 3(c)). The concentration of PGE2 in DS0 was $16205 \pm 2910 \mathrm{pg} / \mathrm{mL}$, $6523 \pm 2823 \mathrm{pg} / \mathrm{mL}$ in DS0.5, and $4507 \pm 396 \mathrm{pg} / \mathrm{mL}$ in DS1, while it was $2704 \pm 415 \mathrm{pg} / \mathrm{mL}$ in PS0 and $3146 \pm 537 \mathrm{pg} / \mathrm{mL}$ in PS0.5. The level of PGE2 in DS0 was significantly higher than that in PSO $(P<0.05)$. There was no significant difference among DS0, DS0.5, and DS1 (Figure 4).

The relative activity of $\beta$-glucuronidase of the colon in DS0 was $346.9 \pm 15.6 \mathrm{nmole} / \mathrm{min} / \mathrm{mg}$ protein, significantly higher than those in PSO (158.4 $\pm 8.8 \mathrm{nmole} / \mathrm{min} / \mathrm{mg}$ protein), DS0.5 (209.6 $\pm 17.1 \mathrm{nmole} / \mathrm{min} / \mathrm{mg}$ protein), and DS1 (163.7 \pm $5.2 \mathrm{nmole} / \mathrm{min} / \mathrm{mg}$ protein $)(P<0.05)$ (Figure 5$)$.

\section{Discussion}

Soy compositions have been shown to have anticancer effects, and the saponins are ones of those that are effective [15]. In this experiment, we demonstrated the effect of the soy saponin consumption on preventing the formation of colon cancer. It was indicated that the size and number of aberrant crypt foci (ACFs) increased as the experiment time increased [16]. Also, the number of ACFs can be an indicator for ACFs development [17]. In this experiment, after the injection of $\mathrm{DMH}$, the number of total ACFs was $27.0 \pm 1.9$, in which the largest one had 6 AC. Thus, with the results of ACFs development, it was applicable to evaluate the effect of saponins on the prevention of colon cancer. The number of ACFs on the colon mucosa is affected by the type, age, and sex of the animal, frequency and dosage of the carcinogen injected, the sections in the colon, and the personnel who is involved in counting ACFs [16]. The mostly used carcinogen for inducing colon cancer in the animal model is azoxymethane (AOM), the metabolite of dimethylhydrazine (DMH) but more toxic than DMH. It was found that the injection of $20 \mathrm{mg} / \mathrm{kg}$ wt of DMH for 5 weeks resulted in 28-30 ACFs $[18,19]$. The injection of AOM in similar dosages produced much more severe symptoms, in which more than $200 \mathrm{ACFs}$ were induced $[20,21]$. In our experiment, rats received $20 \mathrm{mg} / \mathrm{kg}$ wt of DMH twice a week for 6 consecutive weeks that resulted in an average of $27 \mathrm{ACF}$ /rat with 1-6 ACs induced. Thus, using DMH was successful in inducing ACFs and can be used as an alternative method for colon cancer research when using an animal model. In addition to ACFs, the biomarkers for determining the early stages of colon cancer may include mucin-depleted foci (MDF), beta-catenin-accumulated crypts (BCAC), and dysplastic ACF (DACF) $[19,22,23]$. However, ACFs are now 

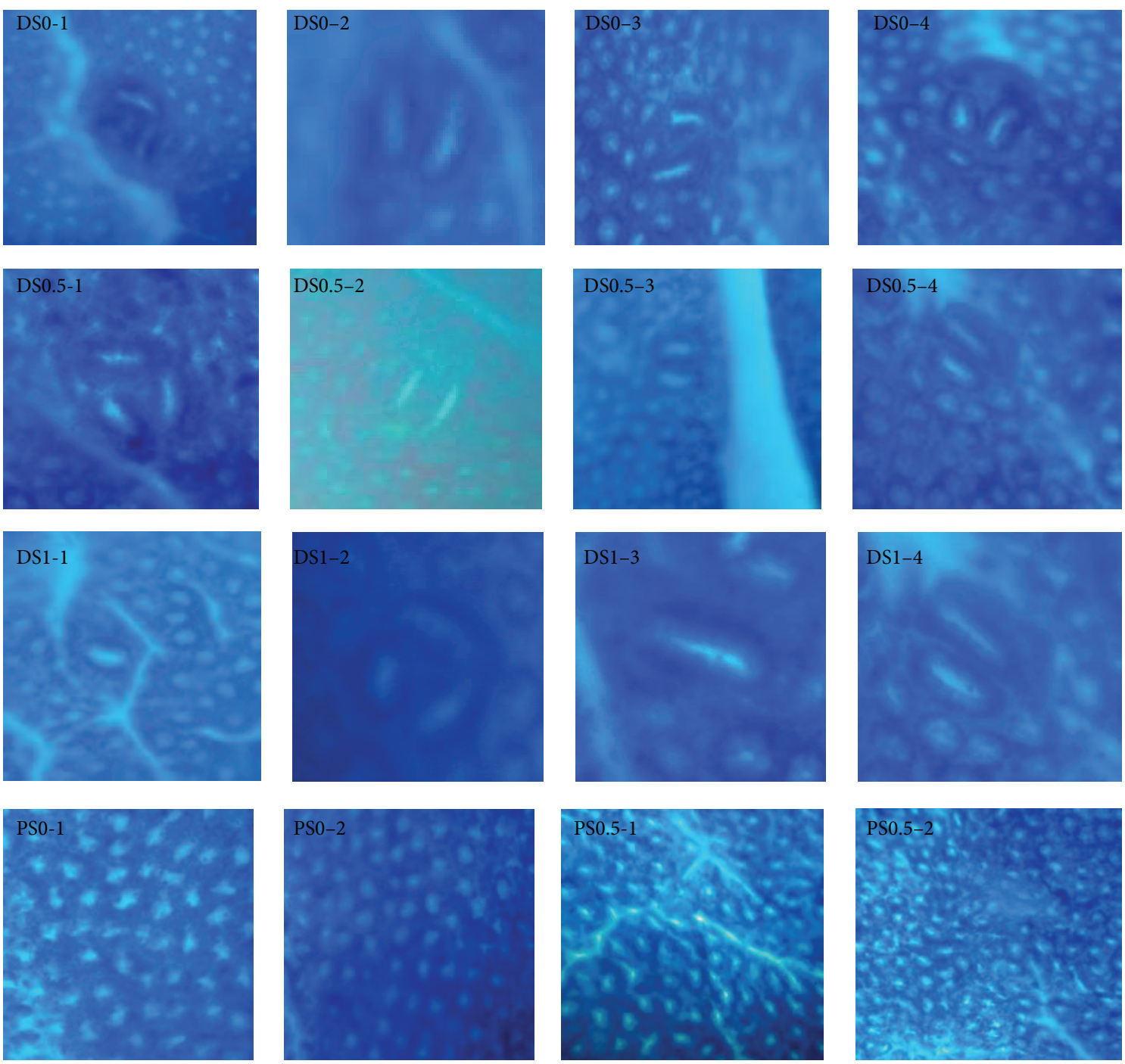

FIGURE 2: The pathological assessment performed by methylene blue staining in the ACFs of the colonic mucosa of rats ${ }^{1,2} \cdot{ }^{1}$ ACFs: aberrant crypt foci. ${ }^{2}$ PS0: received saline and fed AIN93G diet; PS0.5: received saline and fed AIN93G diet containing 0.5\% saponins; DSO: received 1,2-dimethylhydrazine (DMH) and fed AIN93G diet; DS0.5: received DMH and fed AIN93G diet containing 0.5\% saponins; DS1: received DMH and fed AIN93G diet containing $1 \%$ saponins.

TABLE 4: The distribution of ACFs according to different sections of the colon ${ }^{1,2}$.

\begin{tabular}{lccccc}
\hline & ${\text { The incidence of } \mathrm{ACFs}^{3}}$ & Proximal & Middle & Distal & Total \\
\hline PS0 & $0 / 4$ & $\mathrm{ND}^{4}$ & $\mathrm{ND}$ & ND & ND \\
PS0.5 & $0 / 4$ & $\mathrm{ND}$ & $\mathrm{ND}$ & ND & ND \\
DS0 & $6 / 6$ & $4.50 \pm 0.67^{\mathrm{a}}$ & $7.17 \pm 0.62^{\mathrm{a}}$ & $15.50 \pm 1.35^{\mathrm{a}}$ & $27.00 \pm 1.91^{\mathrm{a}}$ \\
DS0.5 & $6 / 6$ & $2.00 \pm 0.28^{\mathrm{ab}}$ & $4.83 \pm 0.33^{\mathrm{a}}$ & $9.83 \pm 0.43^{\mathrm{b}}$ & $16.67 \pm 0.44^{\mathrm{b}}$ \\
DS1 & $6 / 6$ & $1.00 \pm 0.35^{\mathrm{b}}$ & $1.83 \pm 0.50^{\mathrm{b}}$ & $5.17 \pm 0.81^{\mathrm{b}}$ & $8.00 \pm 1.41^{\mathrm{c}}$ \\
\hline
\end{tabular}

${ }^{1}$ Data are expressed as Mean $\pm \operatorname{SEM}(n=6)$.

${ }^{2}$ PS0: received saline and fed AIN93G diet; PS0.5: received saline and fed AIN93G diet containing 0.5\% saponins; DS0: received 1,2-dimethylhydrazine (DMH) and fed AIN93G diet; DS0.5: received DMH and fed AIN93G diet containing 0.5\% saponins; DS1: received DMH and fed AIN93G diet containing 1\% saponins. ${ }^{3}$ The incidence of ACFs is the number of ACF rats/the number of total rats.

${ }^{4} \mathrm{ND}$ : No detection.

${ }^{\mathrm{abc}}$ Letters in each column sharing the different superscripts are significantly different $(P<0.05)$. 


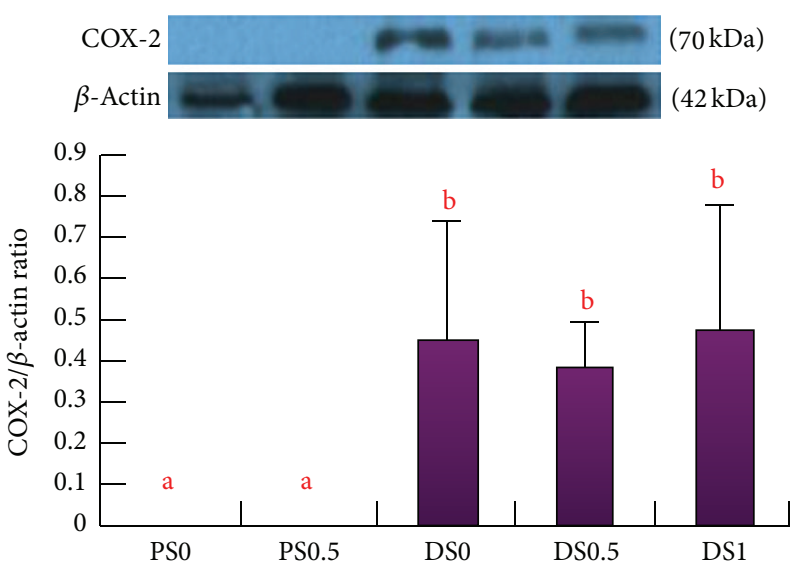

(a)

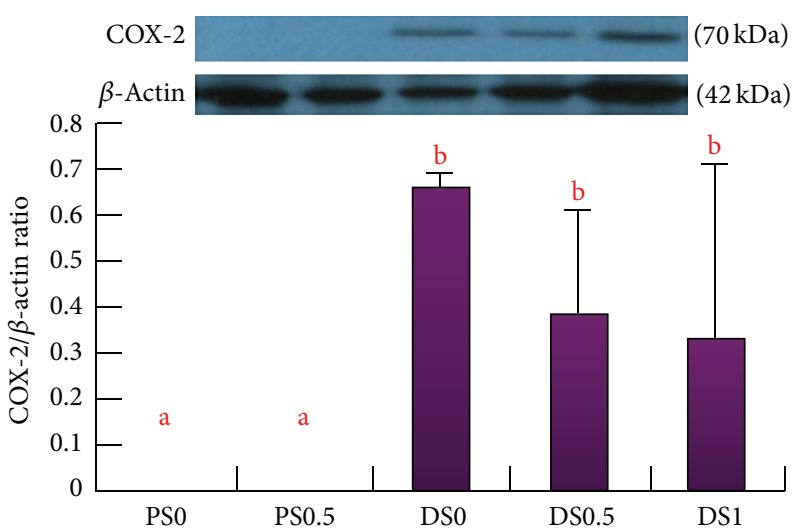

(c)

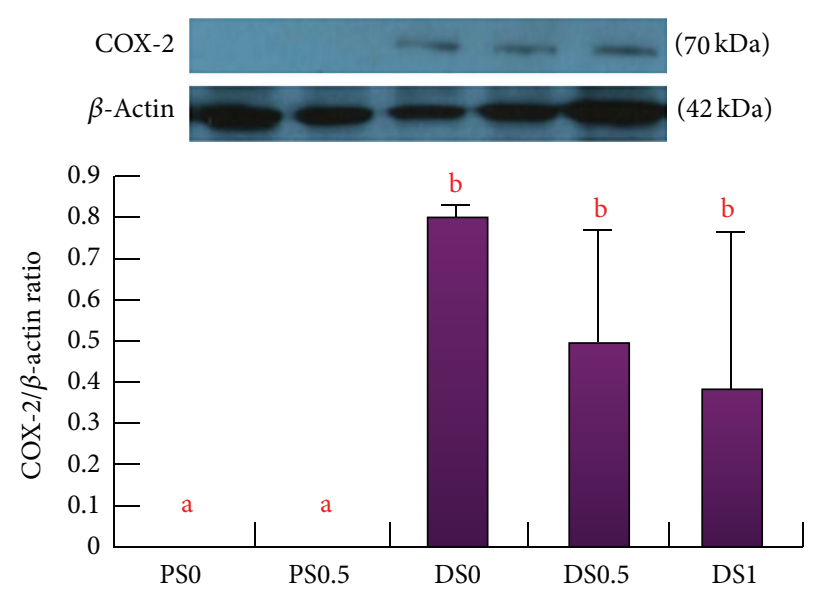

(b)

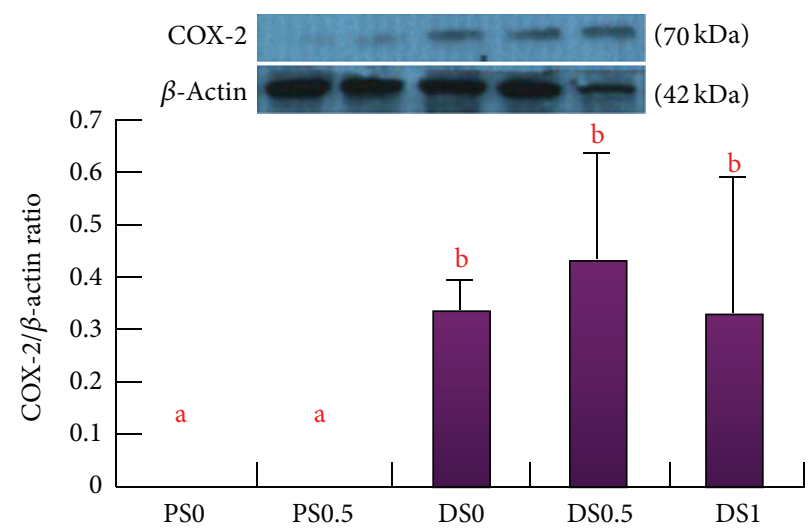

(d)

FIgure 3: The expression of COX-2 protein in the colonic mucosa ${ }^{1,2}$. (a) The total expression of COX-2 protein in the colonic mucosa. (b) The expression of COX-2 protein in proximal colonic mucosa. (c) The expression of COX-2 protein in middle colonic mucosa. (d) The expression of COX-2 protein in distal colonic mucosa. ${ }^{1}$ Data are expressed as mean \pm SEM $(n=3 \sim 4) .{ }^{2}$ The image of western blot was representative. ${ }^{\mathrm{ab}}$ Letters at the top of each bar sharing the different superscripts are significantly different $(P<0.05)$.

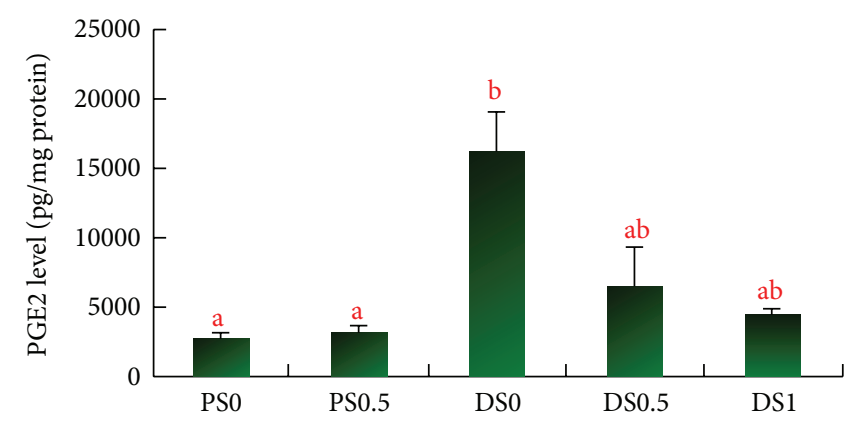

FIGURE 4: The PGE2 levels in the colonic mucosa ${ }^{1,2} .{ }^{1}$ Data are expressed as mean $\pm \operatorname{SEM}(n=3 \sim 4) .{ }^{2} \mathrm{PSO}$ : received saline and fed AIN93G diet; PS0.5: received saline and fed AIN93G diet containing 0.5\% saponins; DSO: received 1,2-dimethylhydrazine (DMH) and fed AIN93G diet; DS0.5: received DMH and fed AIN93G diet containing 0.5\% saponins; DS1: received DMH and fed AIN93G diet containing 1\% saponins. ${ }^{\mathrm{ab}}$ Letters at the top of each bar sharing the different superscripts are significantly different $(P<0.05)$.

used frequently as markers of cancer due to the simplicity in performing without tissue biopsy and the results usually being closely related to the occurrence of tumor [24].

It was shown that soy saponin was effective in inhibiting the growth of the HT-29 human colon cancer cell line by changing the cell morphology and the cell proliferation enzymes [11]. It was indicated that the numbers of total and large aberrant crypt foci (ACF) are reliable indicators of colon cancer occurrence [14]. We found that as the dosage of soy saponin extract in the diet increased, the number 


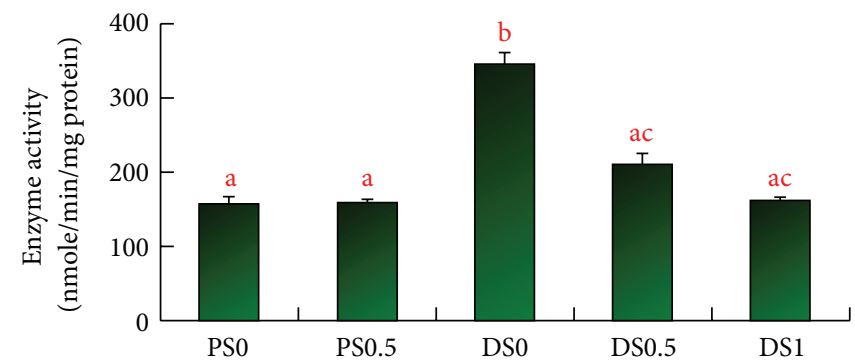

FIGURE 5: The activities of $\beta$-glucuronidase in the colonic mucosa ${ }^{1,2,3} .{ }^{1}$ Data are expressed as mean $\pm \operatorname{SEM}(n=3 \sim 4)$. ${ }^{2}$ PS0: received saline and fed AIN93G diet; PS0.5: received saline and fed AIN93G diet containing 0.5\% saponins; DSO: received 1,2-dimethylhydrazine (DMH) and fed AIN93G diet; DS0.5: received DMH and fed AIN93G diet containing 0.5\% saponins; DS1: received DMH and fed AIN93G diet containing $1 \%$ saponins. ${ }^{3}$ The enzyme activities are derived from the changes of activity at 0 and 60 mins. ${ }^{\text {abc }}$ Letters at the top of each bar sharing the different superscripts are significantly different $(P<0.05)$.

TABLE 5: The change of blood lipid in rats from week 0 to week $15^{1,2}$.

\begin{tabular}{|c|c|c|c|c|c|c|}
\hline Group & & TG (mg/dL) & & & $\mathrm{TC}(\mathrm{mg} / \mathrm{dL})$ & \\
\hline Week & 0 & 15 & $\Delta 0 \sim 15^{*}$ & 0 & 15 & $\Delta 0 \sim 15^{*}$ \\
\hline PS0 & $102.6 \pm 36.6$ & $111.4 \pm 36.4$ & $8.75 \pm 2.9$ & $75.9 \pm 15.7$ & $64.5 \pm 9.6$ & $-11.4 \pm 4.1$ \\
\hline PSO.5 & $140.0 \pm 51.7$ & $169.5 \pm 73.4$ & $29.5 \pm 19.6$ & $71.9 \pm 10.5$ & $75.0 \pm 12.8$ & 3.4 .4 \\
\hline DS0 & $150.6 \pm 43.7$ & $122.4 \pm 29.8$ & $-28.3 \pm 9.4$ & $71.7 \pm 12.1$ & $63.9 \pm 9.7$ & $-7.8 \pm 3.5$ \\
\hline DS0.5 & $111.7 \pm 40.2$ & $90.2 \pm 18.3$ & $-21.4 \pm 7.4$ & $77.3 \pm 15.6$ & $53.9 \pm 20.9$ & $-23.4 \pm 5.0$ \\
\hline DS1 & $126.6 \pm 67.4$ & $91.6 \pm 25.6$ & $-35.0 \pm 11.6$ & $77.0 \pm 15.8$ & $61.3 \pm 10.4$ & $-8.0 \pm 7.7$ \\
\hline
\end{tabular}

${ }^{1}$ Data are expressed as mean $\pm \operatorname{SEM}(n=8 \sim 10)$.

${ }^{2}$ PS0: received saline and fed AIN93G diet; PS0.5: received saline and fed AIN93G diet containing 0.5\% saponins; DSO: received 1,2-dimethylhydrazine (DMH) and fed AIN93G diet; DS0.5: received DMH and fed AIN93G diet containing 0.5\% saponins; DS1: received DMH and fed AIN93G diet containing 1\% saponins. * There was no statistic difference between each other $(P>0.05)$.

of total ACFs decreased. Soy saponins were also found to have cancer-protecting ability by reducing the expression of mRNA and the amount of matrix metalloproteinases (MMP-2 and MMP-9) in HT-1080 cells [25]. It was also shown that triterpenoid B-group soy saponins may induce the autophagic capacity of HTC-15 cells by modulating the activity of extracellular regulated kinase 1/2 (ERK1/2) [26]. A reduced ERK1/2 expression is related to a reduction of ACFs number [27]. However, it was also indicated that the formation of ACFs was more related to a suppressed apoptosis of cancer cells by way of modulating the epidermal growth factor (EGF) signaling pathway rather than the phosphorylated Akt and Erk [28].

Soy isoflavones, different from saponins that cannot be absorbed by the small intestine, also have been found to reduce the occurrences of several cancers including prostate cancers and breast cancers $[29,30]$. A dose of $40 \mathrm{mg} / \mathrm{kg} \mathrm{BW}$ successfully decreased the tumor burden and tumor size in $\mathrm{SD}$ rats [31]. In our experiment, it was due to the fasting time (12 hours) and the short half-life of isoflavone in rats (8.4 hr for genistein and $5.8 \mathrm{hr}$ for daidzein) before the blood was drawn at each time period, that no isoflavone was detected in the blood samples. Also, 1 gram of the soybean saponin extract contained $778.3 \mathrm{mg}$ of saponin and $2.75 \mathrm{mg}$ of isoflavone, including daidzin $1180 \pm 44 \mu \mathrm{g}$, genistin $923 \pm$ $11 \mu \mathrm{g}$, daidzein $173 \pm 58 \mu \mathrm{g}$, and genistein $474 \pm 197 \mu \mathrm{g}$. Rats in the group of $1 \mathrm{X}$ soy saponin extract (DS1) consumed $0.16 \mathrm{~g}$ soy saponin and $0.55 \mathrm{mg}$ isoflavone (daidzin $0.24 \mathrm{mg}$, genistin $0.17 \mathrm{mg}$, daidzein $0.03 \mathrm{mg}$, and genistein $0.09 \mathrm{mg}$ ) a day. It was found that $6,7,4^{\prime}$-trihydroxyisoflavone $\left(6,7,4^{\prime}\right.$ THIF), a metabolite of daidzein, inhibited the growth of HCT-116 human colon cancer cells [32]. 6,7,4'-THIF also arrested the cell cycle of HCT-116 at the $S$ and $G_{2} / M$ phases and reduced the expression of cyclin-dependent kinase 2 (CDK2). Isoflavone may also inhibit the growth of colon cancer cells, DLD-1, by increasing the expression of estrogen receptor (ER)- $\beta$ [31]. Although the isoflavone in the diet might not be enough to lower the risk of colon cancer, but together with saponins, they might have shown a synergic effect on colon cancer inhibition.

Isoflavones and saponins also have blood cholesterol and blood lipid lowering effects. It was indicated [33] that the total blood cholesterol and triglyceride in C57B1/6J mice were decreased by consuming the high-fat diet containing $0.2 \%$ of isoflavone a day. The structure of soy saponins can bind to cholesterol and reduce the absorption of both exogenous and endogenous cholesterol as well as the resorption of bile acid from the gut [34]. However, in our experiment, since the diets were not high-fat diets and the blood lipid level in each group was still in a normal range throughout the experiment period, there was no significant difference in the changes of blood triglyceride and total cholesterol among each group (Table 5).

Cyclooxygenase (COX) and inducible nitric oxides (iNOs) have been used as the index of colon cancer occurrence [35]. Among three types of COX (COX-1-COX-3) only COX-2 gene expression was found to increase in human 
colon cancer [36]. During a cancer progression stage, COX2 activity significantly elevates [37]. Inhibition of COX-2 activity may be a preventive method of colon cancer. In this investigation, however, COX-2 and iNOs activities did not change significantly, which may be due to a not-long-enough experiment period or a not sufficient amount of protein produced. In recent years, $\beta$-glucuronidase activity in the colon has become one of the major indices in the etiology of colon cancer. The enzyme activity increases as the colon cells proliferate abnormally [38]. It was shown that certain types of dietary fiber may have colon cancer preventive effect via changing the secondary bile acids resorption and reducing the activity of bacterial enzymes such as $\beta$-glucuronidase, which plays a role in carcinogenesis [39]. Rats fed with high-fat diet also resulted in elevated levels of bacterial $\beta$-glucuronidase activity in the large intestine [40]. It has been found that $\beta$-glucuronidase activity may be the most important key factor in the genotoxicity of the food-caused colon cancer [41]. In our experiment, the activity of $\beta$ glucuronidase was significantly increased after the injection of DMH and was reduced by consuming the diet containing soy saponins, which indicates that soy saponins can be one of the ingredients for colon cancer prevention. In conclusion, we found that soy saponins reduced the number of ACFs by reducing the activity of $\beta$-glucuronidase in colonic mucosa but not the COX-2 protein expression and PGE2 level.

\section{References}

[1] E. Matos and A. Brandani, "Review on meat consumption and cancer in South America," Mutation Research, vol. 506-507, pp. 243-249, 2002.

[2] I. L. Cameron, W. E. Hardman, and D. W. Heitman, "The nonfermentable dietary fiber lignin alters putative colon cancer risk factors but does not protect against $\mathrm{DMH}$-induced colon cancer in rats," Nutrition and Cancer, vol. 28, no. 2, pp. 170-176, 1997.

[3] B. Farrow and B. M. Evers, "Inflammation and the development of pancreatic cancer," Surgical Oncology, vol. 10, no. 4, pp. 153$169,2002$.

[4] K. Wakabayashi, "NSAIDs as cancer preventive agents," Asian Pacific Journal of Cancer Prevention, vol. 1, no. 2, pp. 97-113, 2000.

[5] J. Botting, "Defining the role of COX-2 inhibitors in inflammatory and other diseases," Drug News and Perspectives, vol. 13, no. 9, pp. 560-566, 2000.

[6] M. Lechner, P. Lirk, and J. Rieder, "Inducible nitric oxide synthase (iNOS) in tumor biology: the two sides of the same coin," Seminars in Cancer Biology, vol. 15, no. 4, pp. 277-289, 2005.

[7] X. P. Hao, T. G. Pretlow, J. S. Rao, and T. P. Pretlow, "Inducible nitric oxide synthase (iNOS) is expressed similarly in multiple aberrant crypt foci and colorectal tumors from the same patients," Cancer Research, vol. 61, no. 2, pp. 419-422, 2001.

[8] Y. Yamamoto and R. B. Gaynor, "Therapeutic potential of inhibition of the NF- $\kappa$ B pathway in the treatment of inflammation and cancer," The Journal of Clinical Investigation, vol. 107, no. 2, pp. 135-142, 2001.

[9] J. Nakamura, Y. Kubota, M. Miyaoka, T. Saitoh, F. Mizuno, and Y. Benno, "Comparison of four microbial enzymes in Clostridia and Bacteroides isolated from human feces," Microbiology and Immunology, vol. 46, no. 7, pp. 487-490, 2002.

[10] A. V. Rao and M.-K. Sung, "Saponins as anticarcinogens," Journal of Nutrition, vol. 125, no. 3, supplement, pp. 717S-724S, 1995.

[11] C. Y. Tsai, Y. H. Chen, Y. W. Chien, W. H. Huang, and S. H. Lin, "Effect of soy saponin on the growth of human colon cancer cells," World Journal of Gastroenterology, vol. 16, no. 27, pp. 33713376, 2010.

[12] C. Y. Lin, C. Y. Tsai, and S. H. Lin, "Effects of soy components on blood and liver lipids in rats fed high-cholesterol diets," World Journal of Gastroenterology, vol. 11, no. 35, pp. 5549-5552, 2005.

[13] O. H. Lowry, N. J. Rosebrough, A. L. Farr, and R. J. Randall, "Protein measurement with the Folin phenol reagent," The Journal of Biological Chemistry, vol. 193, no. 1, pp. 265-275, 1951.

[14] P. Cassand, S. Maziere, M. Champ, K. Meflah, F. Bornet, and J.-F. Narbonne, "Effects of resistant starch- and vitamin Asupplemented diets on the promotion of precursor lesions of colon cancer in rats," Nutrition and Cancer, vol. 27, no. 1, pp. 53-59, 1997.

[15] S. M. Kerwin, "Soy saponins and the anticancer effects of soybeans and soy-based foods," Current Medicinal Chemistry, vol. 4, no. 3, pp. 263-272, 2004.

[16] R. P. Bird and C. K. Good, "The significance of aberrant crypt foci in understanding the pathogenesis of colon cancer," Toxicology Letters, vol. 112-113, pp. 395-402, 2000.

[17] T. Tsukamoto, K. Kozaki, Y. Nishikawa et al., "Development and distribution of 2-amino-1-methyl-6-phenylimidazo[4,5b]pyridine (PhIP)-induced aberrant crypt foci in the rat large intestine," Japanese Journal of Cancer Research, vol. 90, no. 7, pp. 720-725, 1999.

[18] H. S. Park, H. Y. Cho, Y. L. Ha, and J. H. Y. Park, "Dietary conjugated linoleic acid increases the mRNA ratio of Bax/Bcl-2 in the colonic mucosa of rats," Journal of Nutritional Biochemistry, vol. 15, no. 4, pp. 229-235, 2004.

[19] N. Fuku, M. Ochiai, S. Terada, E. Fujimoto, H. Nakagama, and I. Tabata, "Effect of running training on DMH-induced aberrant crypt foci in rat colon," Medicine and Science in Sports and Exercise, vol. 39, no. 1, pp. 70-74, 2007.

[20] A. P. Femia, P. Dolara, A. Giannini, M. Salvadori, A. Biggeri, and G. Caderni, "Frequent mutation of Apc gene in rat colon tumors and mucin-depleted foci, preneoplastic lesions in experimental colon carcinogenesis," Cancer Research, vol. 67, no. 2, pp. 445449, 2007.

[21] N. Suh, S. Paul, X. Hao et al., "Pterostilbene, an active constituent of blueberries, suppresses aberrant crypt foci formation in the azoxymethane-induced colon carcinogenesis model in rats," Clinical Cancer Research, vol. 13, no. 1, pp. 350-355, 2007.

[22] Y. Yamada, N. Yoshimi, Y. Hirose et al., "Frequent $\beta$-catenin gene mutations and accumulations of the protein in the putative preneoplastic lesions lacking macroscopic aberrant crypt foci appearance, in rat colon carcinogenesis," Cancer Research, vol. 60, no. 13, pp. 3323-3327, 2000.

[23] G. Caderni, A. P. Femia, A. Giannini et al., "Identification of mucin-depleted foci in the unsectioned colon of azoxymethane-treated rats: correlation with carcinogenesis," Cancer Research, vol. 63, no. 10, pp. 2388-2392, 2003.

[24] D. E. Corpet and S. Taché, "Most effective colon cancer chemopreventive agents in rats: a systematic review of aberrant crypt foci and tumor data, ranked by potency," Nutrition and Cancer, vol. 43, no. 1, pp. 1-21, 2002. 
[25] J. H. Kang, I. H. Han, M. K. Sung et al., "Soybean saponin inhibits tumor cell metastasis by modulating expressions of MMP-2, MMP-9 and TIMP- 2," Cancer Letters, vol. 261, no. 1, pp. 84-92, 2008.

[26] A. A. Ellington, M. Berhow, and K. W. Singletary, "Induction of macroautophagy in human colon cancer cells by soybean Bgroup triterpenoid saponins," Carcinogenesis, vol. 26, no. 1, pp. 159-167, 2005.

[27] S. J. Lee and K. T. Lim, "Glycine- and proline-rich glycoprotein regulates the balance between cell proliferation and apoptosis for ACF formation in 1,2-dimethylhydrazine-treated A/J mice," Molecular and Cellular Biochemistry, vol. 325, no. 1-2, pp. 187197, 2009.

[28] K. Shiozaki, K. Yamaguchi, I. Sato, and T. Miyagi, "Plasma membrane-associated sialidase (NEU3) promotes formation of colonic aberrant crypt foci in azoxymethane-treated transgenic mice," Cancer Science, vol. 100, no. 4, pp. 588-594, 2009.

[29] J. Wang, I. E. Eltoum, and C. A. Lamartiniere, "Genistein chemoprevention of prostate cancer in TRAMP mice," Journal of Carcinogenesis, vol. 6, article 3, 2007.

[30] C. A. Lamartiniere, J. Wang, M. Smith-Johnson, and I.-E. Eltoum, "Daidzein: bioavailability, potential for reproductive toxicity, and breast cancer chemoprevention in female rats," Toxicological Sciences, vol. 65, no. 2, pp. 228-238, 2002.

[31] J. Raju, A. Bielecki, D. Caldwell et al., "Soy isoflavones modulate azoxymethane-induced rat colon carcinogenesis exposed preand postnatally and inhibit growth of DLD-1 human colon adenocarcinoma cells by increasing the expression of estrogen receptor- $\beta$," Journal of Nutrition, vol. 139, no. 3, pp. 474-481, 2009.

[32] D. E. Lee, K. W. Lee, S. K. Jung et al., “6,7,4'-trihydroxyisoflavone inhibits HCT-116 human colon cancer cell proliferation by targeting CDK1 and CDK2," Carcinogenesis, vol. 32, no. 4, pp. 629-635, 2011.

[33] J. Y. Yang, S. J. Lee, H. W. Park, and Y.-S. Cha, "Effect of genistein with carnitine administration on lipid parameters and obesity in C57B1/6J mice fed a high-fat diet," Journal of Medicinal Food, vol. 9, no. 4, pp. 459-467, 2006.

[34] D. Oakenfull and G. S. Sidhu, "Could saponins be a useful treatment for hypercholesterolaemia?" European Journal of Clinical Nutrition, vol. 44, no. 1, pp. 79-88, 1990.

[35] K. Watanabe, T. Kawamori, S. Nakatsugi, and K. Wakabayashi, "Cox-2 and inos, good targets for chemoprevention of colon cancer," BioFactors, vol. 12, no. 1-4, pp. 129-133, 2000.

[36] C. E. Eberhart, R. J. Coffey, A. Radhika et al., "Up-regulation of cyclooxygenase 2 gene expression in human colorectal adenomas and adenocarcinomas," Gastroenterology, vol. 107, no. 4, pp. 1183-1188, 1994.

[37] R. A. Gupta and R. N. Dubois, "Colorectal cancer prevention and treatment by inhibition of cyclooxygenase-2," Nature Reviews Cancer, vol. 1, no. 1, pp. 11-21, 2001.

[38] D. H. Kim and Y. H. Jin, "Intestinal bacterial $\beta$-glucuronidase activity of patients with colon cancer," Archives of Pharmacal Research, vol. 24, no. 6, pp. 564-567, 2001.

[39] B. S. Reddy, A. Engle, B. Simi, and M. Goldman, "Effect of dietary fiber on colonic bacterial enzymes and bile acids in relation to colon cancer," Gastroenterology, vol. 102, no. 5, pp. 1475-1482, 1992.

[40] B. S. Reddy, S. Mangat, J. H. Weisburger, and E. L. Wynder, "Effect of high-risk diets for colon carcinogenesis on intestinal mucosal and bacterial $\beta$-glucuronidase activity in F344 rats," Cancer Research, vol. 37, no. 10, pp. 3533-3536, 1977.
[41] C. Humblot, M. Murkovic, L. Rigottier-Gois et al., “ $\beta$ glucuronidase in human intestinal microbiota is necessary for the colonic genotoxicity of the food-borne carcinogen 2-amino3-methylimidazo[4,5-f]quinoline in rats," Carcinogenesis, vol. 28, no. 11, pp. 2419-2425, 2007.

[42] P. G. Reeves, F. H. Nielsen, and G. C. Fahey Jr., "AIN-93 purified diets for laboratory rodents: final report of the American Institute of Nutrition ad hoc writing committee on the reformulation of the AIN-76A rodent diet," The Journal of Nutrition, vol. 123, no. 11, pp. 1939-1951, 1993. 


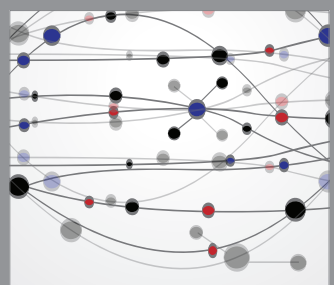

The Scientific World Journal
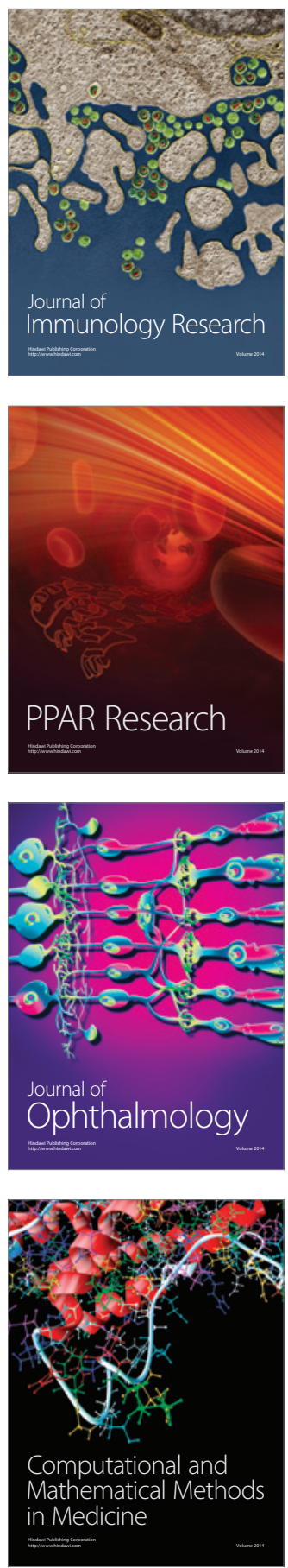

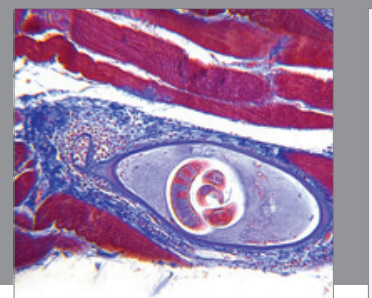

Gastroenterology

Research and Practice
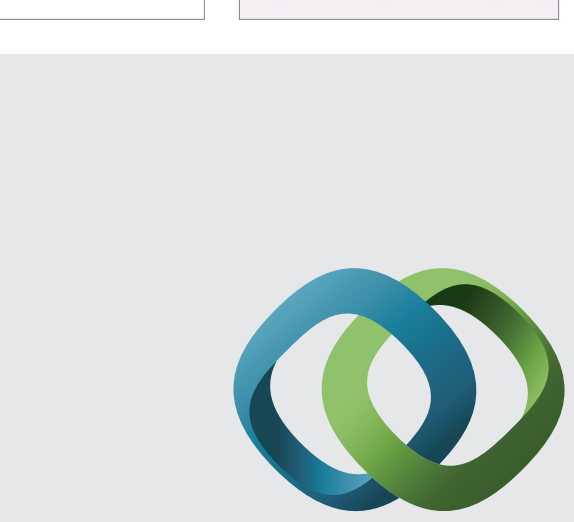

\section{Hindawi}

Submit your manuscripts at

http://www.hindawi.com
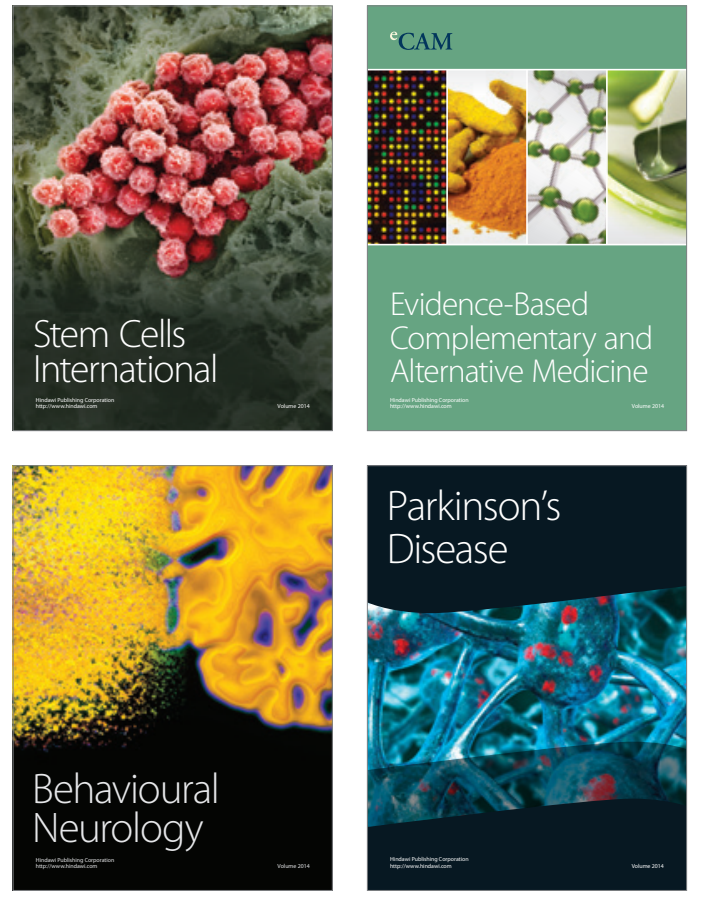
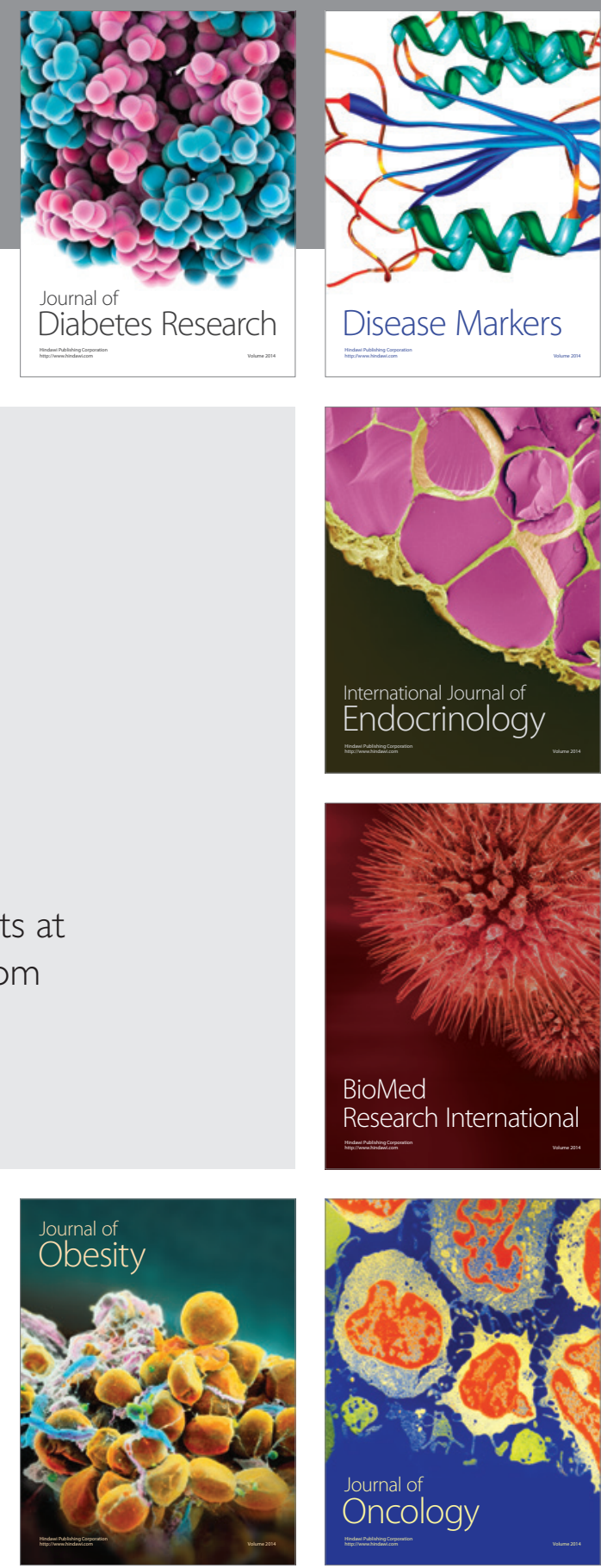

Disease Markers
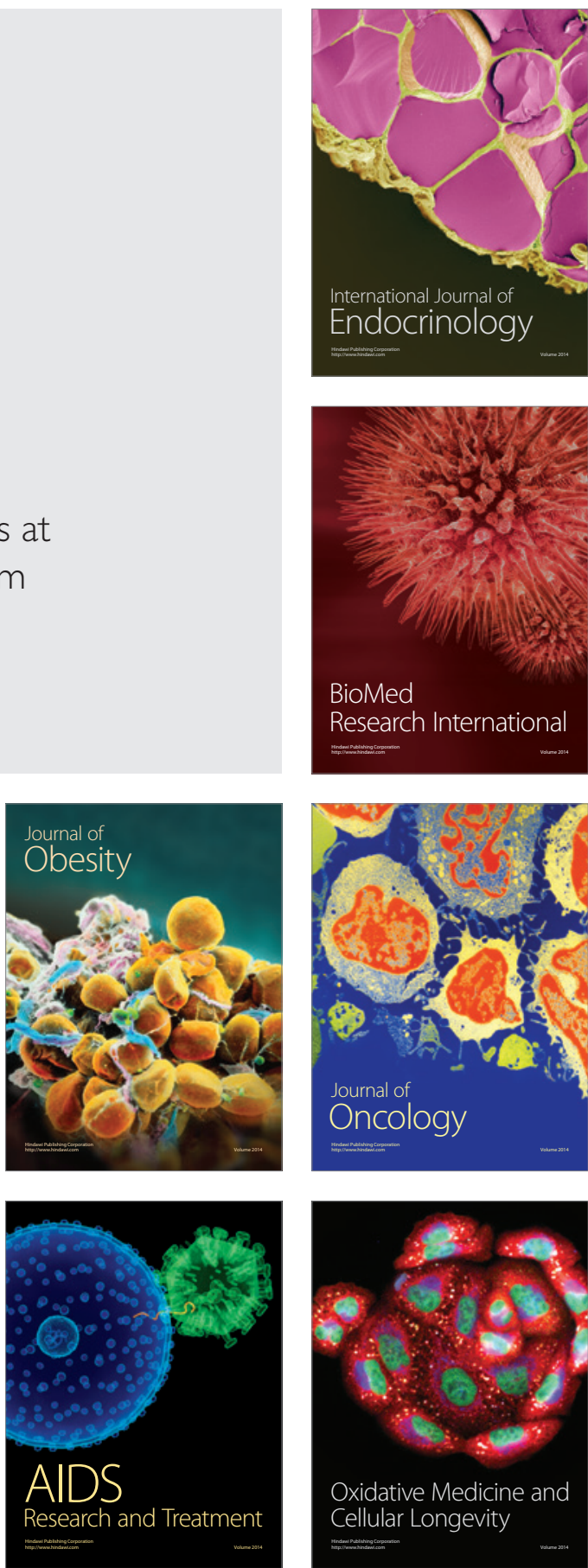